\title{
Coronary Angiography Before and After Renal Transplantation
}

\author{
Mihas Kodenchery, Samrat Bhat, Mohamed El-Ghoroury, Hiroshi \\ Yamasaki and Peter A. McCullough ${ }^{1}$ \\ St. John Providence Health System, St. John Hospital and Medical Center, Detroit, \\ 1 Providence Park Heart Institute, Novi \\ USA
}

\section{Introduction}

Cardiovascular diseases are the leading cause of morbidity and mortality in both dialysis dependent patients and those either waiting for or following up after renal transplantation. Concerns about the risk of contrast-induced acute kidney injury (CI-AKI) associated with coronary angiography in patients with stage 4 or 5 chronic kidney disease (CKD) have sometimes resulted in coronary angiography being delayed until after transplantation. Pretransplant cardiovascular disease is a well established risk factor for post transplant cardiovascular disease and cardiovascular mortality. In addition, post transplant dyslipidemia, ${ }^{1-3}$ hypertension, ${ }^{4-7}$ allograft dysfunction, delayed or slow graft function 8 and post transplant erythrocytosis 9, 10 are some of the more specific factors that increase cardiovascular risk in renal transplant recipients as compared to the general population. Prompt diagnosis and treatment of cardiovascular disease in CKD and end stage renal disease population prior to transplant is aimed to reduce cardiovascular morbidity and mortality in the perioperative period and beyond. Several studies have demonstrated that left ventricular function and hypertrophy improve after renal transplantation. Ferreira et al prospectively studied 24 patients with end stage renal disease and demonstrated a significant decrease in hypertension, reduction in left ventricular hypertrophy and dilation, and improvement in systolic function after successful renal transplantation. ${ }^{11}$ Wali et al followed up 103 renal patients with left ventricular ejection fraction less than $40 \%$ with radionuclide ventriculography and renal transplantation and found the mean left ventricular ejection fraction increased from $31.6 \%$ to $52.2 \%$ at 12 months after transplantation. A longer pre-transplantation interval decreased the likelihood of normalization of ejection fraction. New York Heart Association functional status improved significantly concordant with an improvement of ejection fraction. These studies indicate that renal transplantation should not be withheld for patients with severe cardiac dysfunction as both left ventricular function and survival are expected to improve with renal transplantation. ${ }^{12}$

This chapter will describe the approach to patients with CKD who are being considered for renal transplantation. Careful consideration to the background history, risk of cardiovascular disease, and risk of atherosclerotic events with the transplant operation will be discussed. The risks and benefits of coronary revascularization will be outlined in the 
context of a patient with very little renal function remaining at the time of evaluation. Finally, we will summarize the major caveats for coronary angiography in patients who have received a kidney transplant and are being evaluated for new symptoms.

\section{Preoperative cardiovascular evaluation prior to renal transplantation}

Cardiovascular screening is recommended in certain groups of high risk CKD patients prior to transplantation. ${ }^{13}$ These include persons with diabetes, men over age 45 years, women over 55 years, previous history of ischemic heart disease, an abnormal electrocardiogram, left ventricular dysfunction, smoking history and duration of dialysis more than 2 years. ${ }^{14}$ Controversies exist regarding the ideal screening test for coronary artery disease among exercise stress test, dobutamine stress echocardiogram, and myocardial perfusion studies. Lentine et al in 2008 analyzed the United States Renal Data System on 27,786 eligible patients for renal transplantation and concluded that $46.3 \%$ of patients underwent cardiac evaluation prior to transplantation, of whom $9.5 \%$ required coronary revascularization. Among patients transplanted without cardiovascular evaluation, the three-year incidence of post transplant acute myocardial infarction was 3\% in lower risk group and $10 \%$ in higher risk group. ${ }^{15}$

All patients should be assessed for ischemic heart disease before renal transplantation. The minimum workup required includes a history, physical examination, electrocardiogram, and a chest radiograph. ${ }^{13}$ Assessment of functional status is critical. In general, if a patient can sustain a moderate or high work rate ( $>5$ metabolic equivalents of work) without symptoms, then there is a low risk of perioperative myocardial infarction or cardiovascular death. The pretest probability of coronary artery disease plays a major role in determination of cardiac testing. The Canadian society of transplantation recommends noninvasive testing for symptomatic patients or patients with prior history of coronary artery disease, as well as asymptomatic patients with diabetes mellitus or multiple risk factors for coronary artery disease. ${ }^{17}$ The choice of noninvasive testing has been a matter of debate with nuclear scintigraphy showing a high negative predictive value and performing well in diabetic patients. ${ }^{18-21}$ Marwick et al has shown that the sensitivity of dipyridamole thallium scintigraphy in patients with CKD is lower than that of controls. ${ }^{22}$ The speculated reasons for this observation are reduced coronary flow reserve, left ventricular hypertrophy and interstitial cardiac fibrosis. Results with stress echocardiography have been found to be comparable to nuclear imaging, 23,24 and the expertise of technical and physician personnel often plays the major role in determining which test will be done at each institution. The Society further recommends coronary angiography be performed in patients with a positive noninvasive test or in very high risk patients irrespective of a noninvasive test. De Lima and colleagues have shown that coronary angiography is the best predictor of cardiac events in renal transplant candidates when compared to clinical risk stratification and non invasive testing. ${ }^{16}$ Some centers advocate angiography in most transplant candidates with diabetes, while others pursue cardiac catheterization only in candidates with positive screening examination. ${ }^{25}$ Low risk patients, asymptomatic patients with a negative noninvasive test result or noncritical disease on angiography on appropriate medical therapy, or who have undergone successful intervention can be considered eligible for transplantation without any further evaluation. Coronary angiography remains the gold standard for evaluation of coronary arteries among patients with positive screening tests or high risk of cardiovascular events. It is complicated by its invasive nature and the risk of contrast nephropathy and 
cholesterol embolism which will be discussed below. ${ }^{14}$ The yield of coronary angiography in this population is high. De Lima et al in 2003 found that about $42 \%$ of patients in this group had significant coronary artery stenosis (more than $70 \%$ by visual estimation). Significant coronary artery stenosis was also the most significant predictor of cardiac events at 48 months.16 A suggested approach to preoperative cardiovascular assessment and non invasive stress testing in CKD patients prior to renal transplantation is proposed by Karthikeyan et al in Figure 1.39 Abnormal results on non invasive stress tests such as coronary CT angiography and myocardial perfusion imaging often need invasive coronary angiography for diagnosis and possible intervention. This will lead to unnecessary delay, contrast and radiation exposure. So initial invasive coronary angiography is preferable in patients with multiple co-morbidities and risk factors and those with intermediate to high pre-test probability for non-invasive stress testing.

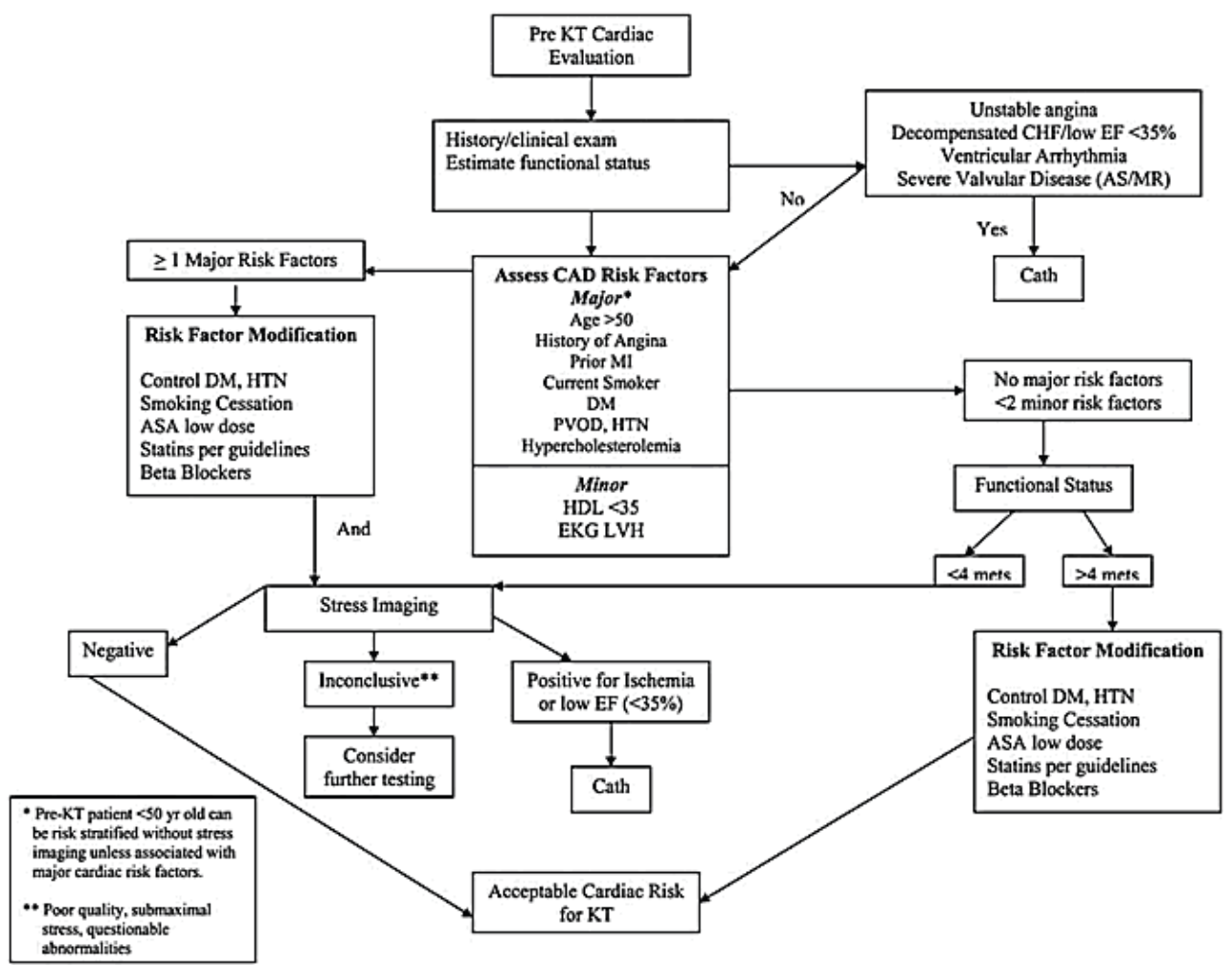

Fig. 1.

Adapted from Cardiology Review (2009); 5: page 183

\section{Risk and benefits of coronary angiography in transplant recipients}

The major risks of coronary angiography in renal transplant candidates are CI-AKI and cholesterol embolism which may hasten the progression to dialysis. In the general population, the risk of CI-AKI is $3.3-14.5 \% .{ }^{26}$ Risk factors include reduced renal filtration 
function, older age, diabetes, congestive heart failure and preprocedure myocardial infarction. ${ }^{27}$ Acute kidney injury requiring dialysis is rare but may occur in 0.44 to $0.77 \%$ of patients. This development is associated with a significant in hospital mortality rate of 35.7 to $39 \%$. The risk of CI-AKI is higher among pretransplant candidates because of their underlying advanced chronic kidney disease and is estimated to be $4-50 \%$ with $8-26 \%$ eventually requiring dialysis at some point prior to transplantation. ${ }^{28}$ Gruberg et al reported that $4.9 \%$ of patients with baseline creatinine more that $1.8 \mathrm{mg} / \mathrm{dl}$ required temporary dialysis after coronary angiography. ${ }^{29}$ Cholesterol embolism occurs from disruption of vascular endothelial plaques resulting in release of cholesterol crystals into the blood stream. In severe forms, it may lead to localized inflammation and fibrosis most commonly seen in the skin, digits, kidney and eye. The reported incidence after coronary angiography is as high as $2 \%$ and manifests as persistent elevation of creatinine up to 3 weeks after the procedure. ${ }^{30}$ The relative contribution of subtle degrees of cholesterol embolism without peripheral signs to AKI is unknown. Further studies are warranted to assess the exact impact of this entity on pretransplant candidates undergoing coronary angiography and evaluate potential measures to reduce their incidence.

\section{Safety of coronary angiography in pretransplant candidates}

Contrast-induced AKI remains an important and potentially avoidable complication after coronary angiography and coronary and vascular interventions. ${ }^{40}$ A direct inverse relationship exists between a patient's estimated glomerular filtration rate (eGFR) and their risk of contrast-induced AKI. ${ }^{41}$ In the setting of severely reduced renal filtration, the risk of sustained intrarenal vasoconstriction, tubular and peritubular stasis of contrast agents, cellular toxicity and permanent loss of functioning nephrons are greatly increased..$^{42}$ Because coronary events are a major cause of perioperative risk and postoperative morbidity in patients considered for renal transplantation, coronary angiography is frequently performed prior to transplantation, particularly in patients with a history of angina or provocable myocardial ischemia on stress testing. ${ }^{43}$ If coronary disease becomes a concern after renal transplantation, the intravascular administration of a contrast agent is associated with a high risk $(>15 \%)$ of contrast-induced AKI in the transplanted kidney. ${ }^{44}$ Thus it is reasonable to consider upfront contrast-induced AKI in the native kidneys before transplantation. Kumar and co-workers reported on the intermediate-term outcomes of 76 predialysis patients with CKD undergoing coronary angiography prior to renal transplantation. ${ }^{45}$ The mean eGFR before contrast exposure was $12.5 \pm 3.4 \mathrm{ml} / \mathrm{min} / 1.73 \mathrm{~m}^{2}$ and the mean iodinated contrast load administered was $55.7 \pm 50.2 \mathrm{ml}$. In total, 25 of the 76 patients $(32.9 \%)$ who had coronary angiography subsequently underwent transplantation; 22 of the patients who underwent transplantation had not received any form of dialysis beforehand. Exposure to contrast media did not seem to hasten progression to end-stage renal disease. The cumulative dialysis-free survival among all 76 patients who had coronary angiography was $89.1 \%$ at 6 months post coronary angiography. A number of factors probably worked together to produce these excellent results and a 'safe landing' after coronary angiography. Patients were stable and relatively young (mean age 56.3 years). Other factors that contributed to favorable outcome include discontinuation of all potentially nephrotoxic drugs 24 hours before the angiogram, use of statins, generous hydration prior to procedure, use of $\mathrm{N}$-acetylcysteine and iso-osmolar contrast and the use of biplane angiography. 
Statins have pleiotropic effects and their anti-oxidant properties may play a role against the oxidative stress involved in the pathogenesis of contrast induced AKI. ${ }^{46,47}$ Hydration prior to administration of contrast may have multiple theoretical benefits for the kidney which include decreased activity of renin angiotensin system, downregulation of tubuloglomerular feedback, augmentation of diuresis and sodium excretion, dilution of contrast media, prevention of renal cortical vasospasm, reduced pre-constriction of vessels, avoidance of tubular obstruction and reduction of endothelin and other renal vasoconstrictors. ${ }^{48}$ Reactive oxygen species generated by radiocontrast in the renal tubules and peritubular space are believed to be central in the pathogenesis of CI-AKI. The potential benefit of N-acetylcysteine has been reported in multiple trials including the Acetylcysteine to Prevent Angiography-Related Renal Tissue Injury trial. ${ }^{49,50}$ But the recently completed, large Acetylcysteine for Contrast-Induced Nephropathy Trial reported by Berwanger and colleagues has cast a doubt on the effectiveness of this agent to prevent this complication. Iodixanol is an iso-osmolar, non ionic dimer used in coronary angiography. It is associated with a significantly lower incidence of AKI after contrast exposure especially in patients with CKD.51 Finally, biplane angiography is associated with a reduction in angiographic contrast volume in patients with CKD. 52, 53 Staging complicated intervention can decrease the contrast volume used in a single session and thus decrease the risk of AKI provided a sufficient long interim time period is observed ( $>10$ days).

Kumar and colleagues have demonstrated that the prudent use of intravascular iodinated contrast agent and coronary revascularization - with due attention to renal protection-did not hasten the progression to end-stage renal disease. Prevention of contrast-induced AKI is almost certainly a product of multimodality prophylaxis after careful patient selection and pre-, intra-, and post-procedural management. ${ }^{4}$ Table 1 lists caveats concerning nephrotoxic medications and other drugs used in routine management with suggestions to possibly reduce adverse events with coronary angiography.

\begin{tabular}{|l|l|l|}
\hline Medications & $\begin{array}{l}\text { Cardiovascular and Renal } \\
\text { Effects }\end{array}$ & Recommendation \\
\hline NSAIDs & $\begin{array}{l}\text { Inhibition of production of } \\
\text { vasodilatory prostaglandins } \\
\text { leading to vasoconstriction of } \\
\text { afferent arterioles, increased } \\
\text { risk of AKI, fluid retention, and } \\
\text { the development of heart failure }\end{array}$ & $\begin{array}{l}\text { Discontinue at least 3 days prior to } \\
\text { contrast exposure, switch to narcotics or } \\
\text { alternative pain treatment }\end{array}$ \\
\hline $\begin{array}{l}\text { Antihypertensive } \\
\text { medications } \\
\text { *Special mention } \\
\text { ACE inhibitors }\end{array}$ & $\begin{array}{l}\text { Reduce the decline in renal } \\
\text { function } \\
\text { Can impair tubuloglomerular } \\
\text { feedback }\end{array}$ & $\begin{array}{l}\text { Continue } \\
\text { Consider holding before angiography }\end{array}$ \\
\hline $\begin{array}{l}\text { Loop, thiazide, } \\
\text { and other diuretics }\end{array}$ & $\begin{array}{l}\text { Volume depletion, electrolyte } \\
\text { abnormalities }\end{array}$ & Hold day of procedure \\
\hline Aminoglycosides & $\begin{array}{l}\text { Interstitial and medullary renal } \\
\text { injury }\end{array}$ & $\begin{array}{l}\text { Avoid if possible, close monitoring by } \\
\text { levels if no alternative }\end{array}$ \\
\hline Vancomycin & $\begin{array}{l}\text { Enhance nephrotoxic potential } \\
\text { of other nephrotoxic } \\
\text { medications, direct } \\
\text { chemotoxicity }\end{array}$ & Continue, closely monitor drug levels \\
\hline
\end{tabular}




\begin{tabular}{|c|c|c|}
\hline Medications & $\begin{array}{l}\text { Cardiovascular and Renal } \\
\text { Effects }\end{array}$ & Recommendation \\
\hline Amphotericin B & $\begin{array}{l}\text { Acute renal vasoconstriction } \\
\text { and distal tubular epithelial } \\
\text { damage, loss of concentrating } \\
\text { ability }\end{array}$ & $\begin{array}{l}\text { Avoid if possible. Intensive monitoring } \\
\text { of renal function, hydration and acid } \\
\text { base status if no alternative or switch to } \\
\text { newer less nephrotoxic agents such as } \\
\text { caspofungin }\end{array}$ \\
\hline Metformin & \begin{tabular}{|l|} 
Increased risk of lactic acidosis \\
if continued after glomerular \\
filtration rate drops
\end{tabular} & $\begin{array}{l}\text { Hold the day of contrast procedure, and } \\
\text { generally recommended for another } 10 \\
\text { days }\end{array}$ \\
\hline Statins & $\begin{array}{l}\text { May be protective against } \\
\text { contrast-induced AKI }\end{array}$ & Continue \\
\hline $\begin{array}{l}\text { Cyclosporine, } \\
\text { tacrolimus }\end{array}$ & $\begin{array}{l}\text { Hypertension, dyslipidemia, } \\
\text { diabetes mellitus, powerful } \\
\text { inhibitor of CYP450 isozyme } \\
\text { 3A4 and increases levels of } \\
\text { some statins including } \\
\text { lovastatin, atorvastatin, and } \\
\text { simvastatin }\end{array}$ & $\begin{array}{l}\text { Hold for three days prior to procedure. } \\
\text { CCB and ACEI preferred choice for } \\
\text { hypertension. To treat dyslipidemia, } \\
\text { consider lowering dose, change to } \\
\text { tacrolimus, diet control and/or lipid- } \\
\text { lowering drugs usually statin with } \\
\text { preference to pravastatin or rosuvastatin } \\
\text { therapy. Watch for statin induced } \\
\text { muscle toxicity/ rhabdomyolysis. Avoid } \\
\text { toxic levels of cyclosporine and monitor } \\
\text { blood glucose closely. Initiate early } \\
\text { therapy for post-transplantation diabetes } \\
\text { mellitus. }\end{array}$ \\
\hline Sirolimus & \begin{tabular}{|l|} 
Dyslipidemia, no significant \\
impact on hypertension or post- \\
transplant diabetes mellitus. It \\
may interact with drugs \\
metabolized by CYP450 \\
isozyme system.
\end{tabular} & $\begin{array}{l}\text { Treat dyslipidemia with diet control plus } \\
\text { lipid-lowering drug therapy usually } \\
\text { statins with preference to pravastatin or } \\
\text { rosuvastatin. Consider lowering dose } \\
\text { and/or change to alternative immune- } \\
\text { suppressant drug if resistant } \\
\text { dyslipidemia. }\end{array}$ \\
\hline Corticosteroids & $\begin{array}{l}\text { Hypertension, dyslipidemia, } \\
\text { hyperglycemia, diabetes } \\
\text { mellitus }\end{array}$ & $\begin{array}{l}\text { Treat hypertension with CCB, ACEI or } \\
\text { beta-blockers. Treat dyslipidemia with } \\
\text { diet control plus lipid-lowering drug } \\
\text { therapy. Monitor blood sugar levels } \\
\text { closely and initiate early therapy for post } \\
\text { transplantation diabetes mellitus. Use of } \\
\text { lower dosing, if possible. }\end{array}$ \\
\hline $\begin{array}{l}\text { Mycophenolate } \\
\text { mofetil and } \\
\text { Azathioprine }\end{array}$ & $\begin{array}{l}\text { Both pose low cardiometabolic } \\
\text { risks. }\end{array}$ & $\begin{array}{l}\text { Monitoring for hypertension, diabetes } \\
\text { mellitus and dyslipidemia when used in } \\
\text { conjunction with any of the above } \\
\text { mentioned immunosuppressant drugs. }\end{array}$ \\
\hline
\end{tabular}

Table 1. Common medications and caveats with respect to coronary angiography in renal transplant candidates or recipients. 


\section{Coronary revascularization in transplant candidates}

Jones et al divided 250 transplant candidates based on coronary angiography into group 1 with less than $50 \%$ stenosis, group 2 with more than $50 \%$ stenosis in 1 vessel, and group 3 with more than $50 \%$ stenosis in 2 or more vessels. Survival was significantly worse in group 3 when compared to groups 1 and 2. However survival was much better in patients who received transplantation in all 3 groups. Therefore severe coronary artery disease should not delay or disqualify a CKD patient from receiving renal transplantation. ${ }^{31}$ Coronary intervention in CKD patients is associated with multiple complicated issues that determine the outcome. Dialysis patients with coronary stenosis of more than $70 \%$ have a higher risk of cardiac events and death than patients without coronary artery lesions. ${ }^{14}$ The Coronary Artery Revascularization Prophylaxis (CARP) trial examined the impact of coronary revascularization in patients requiring major vascular surgery. Revascularization was not associated with any benefit in survival except in patients with left main coronary artery disease. Similarly, the American College of Physicians does not recommend prophylactic revascularization of asymptomatic patients undergoing noncardiac surgery, stressing the fact that asymptomatic low risk pretransplant candidates do not need coronary revascularization for renal transplantation. ${ }^{32}$ Kasiske et al suggested that revascularization of significant coronary artery stenosis should occur prior to renal transplantation. ${ }^{13}$ The prolonged survival benefit was confined to left main coronary artery stenosis, left main equivalent disease, triple vessel disease with abnormal left ventricular function, and two vessel disease with more than $75 \%$ stenosis of the left anterior descending artery. Revascularization is recommended for left main disease and its equivalents and symptomatic patients refractory to medical treatments. ${ }^{33}$ Manske et al randomized 26 diabetic pretransplant candidates with significant coronary artery disease into revascularization and medical therapy groups prior to renal transplantation. The outcome of patients managed medically was significantly inferior to those treated by revascularization. Only 2 out of 13 revascularized patients had cardiovascular end points when compared to 10 out of 13 in the medically managed group. ${ }^{34}$ Coronary revascularization in renal patients is associated with a three fold increase in mortality when compared to patients not requiring renal replacement therapy. ${ }^{35}$ Compared to percutaneous coronary intervention, coronary artery bypass grafting is associated with approximately three time greater short term risk of postoperative hemodialysis dependence among non-hemodialysis dependent CKD patients. ${ }^{36}$ Similarly, survival rates are significantly lower in dialysis patients at 2 years when compared to the general population. ${ }^{35}$ Percutaneous coronary intervention is shown to have a better in hospital and 30 day survival in dialysis patients when compared to coronary artery bypass surgery. However coronary artery bypass surgery has better long term survival. ${ }^{37}$ It also appears that there is a higher rate of restenosis of revascularized vessels in patients with CKD. ${ }^{38}$ The use of drug eluting stents may decrease the incidence of restenosis, however these stents mandate the use of aspirin and clopidogrel for at least 1 year as per the present guidelines. Premature discontinuation of an antiplatelet agent is associated with significant risk of stent thrombosis. Thus, the combined use of aspirin and clopidogrel may delay renal transplantation. For that reason, if coronary intervention is contemplated, bare metal stent, balloon angioplasty or bypass grafting should be considered if the anatomy is feasible. ${ }^{39}$ 


\section{Angiography in patients after renal transplantation}

Coronary angiography continues to be the gold standard for identifying coronary artery disease even in post transplant patients. Renal transplantation does not protect one from the adverse effect of contrast on the kidney. Transplant recipients are at high risk of CI-AKI due to chronic allograft dysfunction and the high prevalence of diabetes and concomitant use of immunosuppressants like cyclosporine and tacrolimus. Agrawal et al found a $15.4 \%$ incidence of contrast induced nephropathy among post transplant patients undergoing coronary angiography. Intravenous hydration, bicarbonate infusion, $\mathrm{N}$-acetylcysteine and the use of iso-osmolar contrast agent show varying efficacy in reducing its incidence. ${ }^{44}$ Thus, the renal transplant recipient, appears to be at enhanced risk for CI-AKI compared to patients with similar glomerular filtration and bilateral native kidneys. Renal transplant recipients should be informed of this increased risk and unnecessary or optional contrast exposure should be avoided.

\section{Conclusions}

There are specific cardiovascular benefits to early renal transplantation in CKD patients including improved left ventricular function, enhanced overall functional capacity and quality of life, and decreased morbidity and mortality. Delay in renal transplantation and longer duration of hemodialysis decreases the likelihood of normalization of cardiac systolic dysfunction after transplantation. CKD patient with cardiac dysfunction should be thoroughly evaluated for underlying ischemia and aggressively treated with anti-anginals, angiotensin converting enzyme inhibitors or angiotensin receptor blockers and beta blockers before, perioperatively, and after renal transplantation. Every effort must be made to promote early renal transplantation when feasible with a living donor. ${ }^{12}$ An early cardiovascular assessment, preferably by cautious coronary angiography utilizing the above mentioned renoprotective measures should be performed if indicated, to decrease the cardiovascular event rate associated with transplant surgery. A multidisciplinary approach involving a cardiologist, an interventionist, a nephrologist, a cardiothoracic and transplant surgeon can expedite the process and thus improve post transplant morbidity, mortality, functional capacity and overall quality of life.

\section{Abbreviations}

$\mathrm{KT}=$ Kidney transplantation,

$\mathrm{CAD}=$ Coronary artery disease,

$\mathrm{CHF}=$ Congestive Heart Failure,

$\mathrm{EKG}=$ Electrocardiogram,

$\mathrm{EF}=$ Ejection Fraction,

$\mathrm{MI}=$ Myocardial infarction,

DM = Diabetes mellitus,

AS = Aortic stenosis,

$\mathrm{MR}=$ Mitral regurgitation,

LDL = Low density lipoprotein,

PVOD $=$ Peripheral vascular disease, 
CI-AKI = Contrast induced acute kidney injury,

NSAIDs = Non steroidal anti-inflammatory drugs,

$\mathrm{AKI}=$ acute kidney injury,

$\mathrm{CCB}=$ calcium channel blockers,

$\mathrm{ACEI}=$ angiotensin converting enzyme inhibitors,

eGFR = estimated glomerular filtration rate,

MDRD $=$ Modification of Diet in Renal Disease,

$\mathrm{AKI}=$ Acute Kidney Injury,

$\mathrm{CKD}=$ Chronic Kidney Disease,

$\mathrm{ESRD}=$ End Stage Renal Disease

\section{References}

[1] Kasiske BL, Vazquez MA, Harmon WE, et al. Recommendations for the outpatient surveillance of renal transplant recipients. American Society of Transplantation. J. Am. Soc. Nephrol. 2000;11 Suppl 15:S1-86.

[2] Meier-Kriesche H, Baliga R, Kaplan B. Decreased renal function is a strong risk factor for cardiovascular death after renal transplantation. Transplantation. 2003;75(8):1291-1295.

[3] Mortazavi M, Tohidi M, Rahbani-Nobar M. Evaluation of serum levels of lipids and lipoproteins in kidney-transplanted patients. Transplant. Proc. 2001;33(5):2689-2690.

[4] Pérez Fontán M, Rodríguez-Carmona A, García Falcón T, Fernández Rivera C, Valdés F. Early immunologic and nonimmunologic predictors of arterial hypertension after renal transplantation. Am. J. Kidney Dis. 1999;33(1):21-28.

[5] Zeier M, Mandelbaum A, Ritz E. Hypertension in the transplanted patient. Nephron. 1998;80(3):257-268.

[6] Kobashigawa JA, Kasiske BL. Hyperlipidemia in solid organ transplantation. Transplantation. 1997;63(3):331-338.

[7] Guidi E, Menghetti D, Milani S, et al. Hypertension may be transplanted with the kidney in humans: a long-term historical prospective follow-up of recipients grafted with kidneys coming from donors with or without hypertension in their families. J. Am. Soc. Nephrol. 1996;7(8):1131-1138.

[8] First MR, Neylan JF, Rocher LL, Tejani A. Hypertension after renal transplantation. J. Am. Soc. Nephrol. 1994;4(8 Suppl):S30-36.

[9] Kasiske BL. Risk factors for accelerated atherosclerosis in renal transplant recipients. Am. J. Med. 1988;84(6):985-992.

[10] Wickre CG, Norman DJ, Bennison A, Barry JM, Bennett WM. Postrenal transplant erythrocytosis: a review of 53 patients. Kidney Int. 1983;23(5):731-737.

[11] Ferreira SRC, Moisés VA, Tavares A, Pacheco-Silva A. Cardiovascular effects of successful renal transplantation: a 1-year sequential study of left ventricular morphology and function, and 24-hour blood pressure profile. Transplantation. 2002;74(11):1580-1587.

[12] Wali RK, Wang GS, Gottlieb SS, et al. Effect of kidney transplantation on left ventricular systolic dysfunction and congestive heart failure in patients with end-stage renal disease. J. Am. Coll. Cardiol. 2005;45(7):1051-1060. 
[13] Kasiske BL, Cangro CB, Hariharan S, et al. The evaluation of renal transplantation candidates: clinical practice guidelines. Am. J. Transplant. 2001;1 Suppl 2:3-95.

[14] Pilmore H. Cardiac assessment for renal transplantation. Am. J. Transplant. 2006;6(4):659-665.

[15] Lentine KL, Schnitzler MA, Brennan DC, et al. Cardiac evaluation before kidney transplantation: a practice patterns analysis in Medicare-insured dialysis patients. Clin J Am Soc Nephrol. 2008;3(4):1115-1124.

[16] De Lima JJG, Sabbaga E, Vieira MLC, et al. Coronary angiography is the best predictor of events in renal transplant candidates compared with noninvasive testing. Hypertension. 2003;42(3):263-268.

[17] Knoll G, Cockfield S, Blydt-Hansen T, et al. Canadian Society of Transplantation: consensus guidelines on eligibility for kidney transplantation. CMAJ. 2005;173(10):S1-25.

[18] Patel AD, Abo-Auda WS, Davis JM, et al. Prognostic value of myocardial perfusion imaging in predicting outcome after renal transplantation. Am. J. Cardiol. 2003;92(2):146-151.

[19] Feola M, Biggi A, Ribichini F, et al. Predicting cardiac events with Tl201 dipyridamole myocardial scintigraphy in renal transplant recipients. J. Nephrol. 2002;15(1):48-53.

[20] Le A, Wilson R, Douek K, et al. Prospective risk stratification in renal transplant candidates for cardiac death. Am. J. Kidney Dis. 1994;24(1):65-71.

[21] Derfler K, Kletter K, Balcke P, Heinz G, Dudczak R. Predictive value of thallium-201dipyridamole myocardial stress scintigraphy in chronic hemodialysis patients and transplant recipients. Clin. Nephrol. 1991;36(4):192-202.

[22] Marwick TH, Steinmuller DR, Underwood DA, et al. Ineffectiveness of dipyridamole SPECT thallium imaging as a screening technique for coronary artery disease in patients with end-stage renal failure. Transplantation. 1990;49(1):100-103.

[23] West JC, Napoliello DA, Costello JM, et al. Preoperative dobutamine stress echocardiography versus cardiac arteriography for risk assessment prior to renal transplantation. Transpl. Int. 2000;13 Suppl 1:S27-30.

[24] Herzog CA, Marwick TH, Pheley AM, et al. Dobutamine stress echocardiography for the detection of significant coronary artery disease in renal transplant candidates. Am. J. Kidney Dis. 1999;33(6):1080-1090.

[25] Manske CL, Thomas W, Wang Y, Wilson RF. Screening diabetic transplant candidates for coronary artery disease: identification of a low risk subgroup. Kidney Int. 1993;44(3):617-621.

[26] Rihal CS, Textor SC, Grill DE, et al. Incidence and prognostic importance of acute renal failure after percutaneous coronary intervention. Circulation. 2002;105(19):22592264.

[27] Lindsay J, Apple S, Pinnow EE, et al. Percutaneous coronary intervention-associated nephropathy foreshadows increased risk of late adverse events in patients with normal baseline serum creatinine. Catheter Cardiovasc Interv. 2003;59(3):338-343.

[28] Lorenz EC, Stegall MD, Cosio FG, et al. The effect of coronary angiography on renal function in preemptive renal transplant candidates. Clin Transplant. 2010. Available at: http://www.ncbi.nlm.nih.gov/pubmed/21050272. 
[29] Gruberg L, Dangas G, Mehran R, et al. Clinical outcome following percutaneous coronary interventions in patients with chronic renal failure. Catheter Cardiovasc Interv. 2002;55(1):66-72.

[30] Saklayen MG, Gupta S, Suryaprasad A, Azmeh W. Incidence of atheroembolic renal failure after coronary angiography. A prospective study. Angiology. 1997;48(7):609613.

[31] Jones DG, Taylor AM, Enkiri SA, et al. Extent and severity of coronary disease and mortality in patients with end-stage renal failure evaluated for renal transplantation. Am. J. Transplant. 2009;9(8):1846-1852.

[32] McFalls EO, Ward HB, Moritz TE, et al. Coronary-artery revascularization before elective major vascular surgery. N. Engl. J. Med. 2004;351(27):2795-2804.

[33] Eleven-year survival in the Veterans Administration randomized trial of coronary bypass surgery for stable angina. The Veterans Administration Coronary Artery Bypass Surgery Cooperative Study Group. N. Engl. J. Med. 1984;311(21):1333-1339.

[34] Manske CL, Wang Y, Rector T, Wilson RF, White CW. Coronary revascularisation in insulin-dependent diabetic patients with chronic renal failure. Lancet. 1992;340(8826):998-1002.

[35] Herzog CA, Ma JZ, Collins AJ. Comparative survival of dialysis patients in the United States after coronary angioplasty, coronary artery stenting, and coronary artery bypass surgery and impact of diabetes. Circulation. 2002;106(17):2207-2211.

[36] Ashrith G, Lee V, Elayda MA, Reul RM, Wilson JM. Short- and long-term outcomes of coronary artery bypass grafting or drug-eluting stent implantation for multivessel coronary artery disease in patients with chronic kidney disease. Am. J. Cardiol. 2010;106(3):348-353.

[37] Herzog CA, Ma JZ, Collins AJ. Long-term outcome of dialysis patients in the United States with coronary revascularization procedures. Kidney Int. 1999;56(1):324-332.

[38] Sadeghi HM, Stone GW, Grines CL, et al. Impact of renal insufficiency in patients undergoing primary angioplasty for acute myocardial infarction. Circulation. 2003;108(22):2769-2775.

[39] Karthikeyan V, Ananthasubramaniam K. Coronary risk assessment and management options in chronic kidney disease patients prior to kidney transplantation. Curr Cardiol Rev. 2009;5(3):177-186.

[40] McCullough PA. Contrast-induced acute kidney injury. J. Am. Coll. Cardiol. 2008;51(15):1419-1428.

[41] McCullough PA, Adam A, Becker CR, et al. Risk prediction of contrast-induced nephropathy. Am. J. Cardiol. 2006;98(6A):27K-36K.

[42] McCullough PA. Radiocontrast-induced acute kidney injury. Nephron Physiol. 2008; 109(4):p61-72.

[43] Keeley EC, McCullough PA. Coronary revascularization in patients with end-stage renal disease: risks, benefits, and optimal strategies. Rev Cardiovasc Med. 2003;4(3):125-130.

[44] Agrawal V, Swami A, Kosuri R, et al. Contrast-induced acute kidney injury in renal transplant recipients after cardiac catheterization. Clin. Nephrol. 2009;71(6):687-696.

[45] Kumar N, Dahri L, Brown W, et al. Effect of elective coronary angiography on glomerular filtration rate in patients with advanced chronic kidney disease. Clin J Am Soc Nephrol. 2009;4(12):1907-1913. 
[46] McCullough PA, Rocher LR. Statin therapy in renal disease: harmful or protective? Curr. Diab. Rep. 2007;7(6):467-473.

[47] Katholi RE, Woods WT, Taylor GJ, et al. Oxygen free radicals and contrast nephropathy. Am. J. Kidney Dis. 1998;32(1):64-71.

[48] Erley CM. Does hydration prevent radiocontrast-induced acute renal failure? Nephrol. Dial. Transplant. 1999;14(5):1064-1066.

[49] Kelly AM, Dwamena B, Cronin P, Bernstein SJ, Carlos RC. Meta-analysis: effectiveness of drugs for preventing contrast-induced nephropathy. Ann. Intern. Med. 2008;148(4):284-294.

[50] Diaz-Sandoval LJ, Kosowsky BD, Losordo DW. Acetylcysteine to prevent angiographyrelated renal tissue injury (the APART trial). Am. J. Cardiol. 2002;89(3):356-358.

[51] McCullough PA, Bertrand ME, Brinker JA, Stacul F. A meta-analysis of the renal safety of isosmolar iodixanol compared with low-osmolar contrast media. J. Am. Coll. Cardiol. 2006;48(4):692-699.

[52] Goldfarb S, McCullough PA, McDermott J, Gay SB. Contrast-induced acute kidney injury: specialty-specific protocols for interventional radiology, diagnostic computed tomography radiology, and interventional cardiology. Mayo Clin. Proc. 2009;84(2):170-179.

[53] Kane GC, Doyle BJ, Lerman A, et al. Ultra-low contrast volumes reduce rates of contrast-induced nephropathy in patients with chronic kidney disease undergoing coronary angiography. J. Am. Coll. Cardiol. 2008;51(1):89-90. 


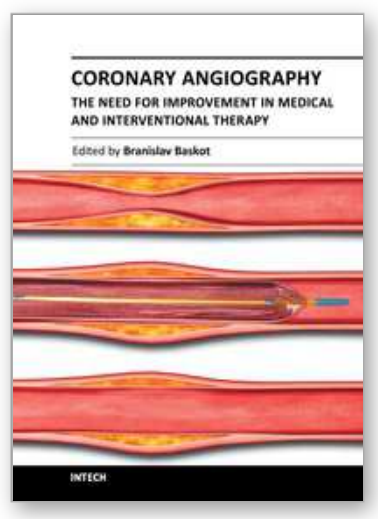

\section{Coronary Angiography - The Need for Improvement in Medical and Interventional Therapy}

Edited by Prof. Baskot Branislav

ISBN 978-953-307-641-6

Hard cover, 206 pages

Publisher InTech

Published online 06, September, 2011

Published in print edition September, 2011

In this book we examined a periprocedural complication of coronary angiography, and coronary intervention. That includes related to cardiac catheterization and diagnostic coronary angiography, and those that occur as a consequence of the specific equipment. However, improvements in devices, the use of stents, and aggressive antiplatelet therapy have significantly reduced the incident of major periprocedural complications. This book giving knowledge and experiences many of interventional cardiologists from all over the world, and provide possibility to recognize new approach in this domain. Book gives lecture on how we image and how we decide on what to treat, how to treat it, and then results of that treatment. They offer many answers to what we have today and what we will have tomorrow.

\section{How to reference}

In order to correctly reference this scholarly work, feel free to copy and paste the following:

Mihas Kodenchery, Samrat Bhat, Mohamed El-Ghoroury, Hiroshi Yamasaki and Peter A. McCullough (2011). Coronary Angiography Before and After Renal Transplantation, Coronary Angiography - The Need for Improvement in Medical and Interventional Therapy, Prof. Baskot Branislav (Ed.), ISBN: 978-953-307-641-6, InTech, Available from: http://www.intechopen.com/books/coronary-angiography-the-need-for-improvement-inmedical-and-interventional-therapy/coronary-angiography-before-and-after-renal-transplantation1

\section{INTECH}

open science | open minds

\author{
InTech Europe \\ University Campus STeP Ri \\ Slavka Krautzeka 83/A \\ 51000 Rijeka, Croatia \\ Phone: +385 (51) 770447 \\ Fax: +385 (51) 686166 \\ www.intechopen.com
}

\author{
InTech China \\ Unit 405, Office Block, Hotel Equatorial Shanghai \\ No.65, Yan An Road (West), Shanghai, 200040, China \\ 中国上海市延安西路65号上海国际贵都大饭店办公楼 405 单元 \\ Phone: +86-21-62489820 \\ Fax: $+86-21-62489821$
}


(C) 2011 The Author(s). Licensee IntechOpen. This chapter is distributed under the terms of the Creative Commons Attribution-NonCommercialShareAlike-3.0 License, which permits use, distribution and reproduction for non-commercial purposes, provided the original is properly cited and derivative works building on this content are distributed under the same license. 